\title{
Temporal progression in migratory status and sexual maturation in European silver eels during downstream migration
}

\author{
Arjan P. Palstra • Ma. Angeles Guerrero • \\ Gerard de Laak · Jan P. G. Klein Breteler • \\ Guido E. E. J. M. van den Thillart
}

Received: 4 February 2011 / Accepted: 14 February 2011/Published online: 10 May 2011

(C) The Author(s) 2011. This article is published with open access at Springerlink.com

\begin{abstract}
The onset of downstream migration of European eels is accompanied by a cessation of feeding and the start of sexual maturation which stresses the link between metabolism and sexual maturation, also suggesting an important role for exercise. Exercise has been tested with eels in swim tunnels and was found to stimulate the onset of sexual maturation. In this study, we have investigated the interplay between migration and maturation in the field during the downstream migration of female
\end{abstract}

A. P. Palstra - Ma. A. Guerrero .

G. E. E. J. M. van den Thillart

Molecular Cell Biology, Institute of Biology, Leiden

University (IBL), Sylvius Laboratory, Leiden,

The Netherlands

\section{A. P. Palstra}

Departament de Fisiologia, Facultat de Biologia, Universitat de Barcelona and Institut de Biomedicina de la Universitat de Barcelona (IBUB), Barcelona, Spain

\section{A. P. Palstra ( $\square)$}

Institute for Marine Resources and Ecosystem Studies (IMARES) of the Wageningen University, P.O. Box 77, 4400 AB Yerseke, The Netherlands

e-mail: arjanpalstra@gmail.com

G. de Laak

Sportvisserij Nederland, Bilthoven, The Netherlands

J. P. G. Klein Breteler

VIVION BV, Utrecht, The Netherlands silver eels. Temporal changes in migratory status and sexual maturation among silver eels of the upstream Rhine River system over 3 months of the migration season (August, September and October) were determined in biometrical parameters, plasma $17 \beta$-estradiol and calcium levels, oocyte histology and gonadal fat levels. Furthermore, the ecological relevant parameters age as determined by otolithometry and health aspects indicated by haematocrit, haemoglobin and swim-bladder parasite load were measured. Silver eels were estimated to be 14 years old. A strong temporal progression in migratory stage was shown over the months of downstream migration. Catches probably represented a mix of reproductive migrants and feeding migrants of which the ratio increased over time. Furthermore, this study confirmed our hypothesis linking the migratory stage to early maturation as indicated by enlargement of the eyes, oocyte growth and fat deposition in the oocytes, exactly the same changes as found induced by exercise but not ruling out environmental influences. Migrants show extensive fat uptake by the oocytes, probably stimulated by the swimming exercise. In addition, at least $83 \%$ of the silver eels in this spawning run may have suffered from negative effects of swim-bladder parasites on their swimming performance.

Keywords Anguilla anguilla $\cdot$ Swimming exercise · Reproductive migration · Energy metabolism ·

Puberty $\cdot$ Rhine silver eel project 


\section{Introduction}

Fish species that migrate long distances to their spawning grounds like anguillids and salmonids require at the start of their migration a metabolic switch for the mobilisation of energy reserves. This mobilisation is not only needed to fuel migration but also to allow gonadal maturation linked to deposition of fats and yolk in the oocytes (Palstra et al. 2010a). Furthermore, a hormonal switch is required to sexually mature. The question of how the metabolic status determines the onset of sexual reproduction is still largely unsolved but pivotal in understanding the reproductive physiology of fish.

Every year in autumn, the majority of the large $(>70 \mathrm{~cm})$ female yellow eels (Anguilla anguilla) experience drastic physiological and morphological changes and become silver eels ('silvering'; Durif et al. 2009). This should not be considered as a true metamorphosis, since it is not an abrupt change but a gradual and reversible one (Svedäng and Wickström 1997). The gradual change is described by the silver index by Durif et al. (2005), which is based on length, weight, eye size and pectoral fin length. Recently, the silvering process has been considered as the start of puberty (Aroua et al. 2005). Moreover, Durif's silver index correlates with a higher gonadosomatic index (GSI) and higher LH levels in the pituitary of migrants. The fact that the onset of sexual maturation is accompanied by a cessation of feeding and the start of migration suggests a close relation between sexual maturation, metabolism and exercise.

Numerous long-term swimming trials have been carried out to study the effect of swimming on the onset of sexual maturation of European eels (reviewed by Palstra et al. 2009; van den Thillart et al. 2009; Palstra and van den Thillart 2010). Swimming in freshwater by migrant eels was found to stimulate the early sexual maturation as evidenced by enlargement of the eyes, oocyte growth and fat deposition in the oocytes (Palstra et al. 2007a; Palstra and van den Thillart 2010) and increased LH content in the pituitary (van Ginneken et al. 2007a). Swimming stimulated previtellogenic oocyte development during the lipid vescicle stage. Hepatic vitellogenesis as indicated by low plasma calcium $(\mathrm{Ca})$ levels of European eels in freshwater was not observed under those conditions.

Downstream migration of silver eels in the Rhine River system starts in August and continues until water temperature drops below $6^{\circ} \mathrm{C}$ (Tesch 1972), which usually occurs in November. During the months of the autumn spawning run, not all silver eels are migratory; some may start their journey later in the year or may even wait until the next year (stage-3 premigrants; Durif et al. 2005) in contrast to the migrants (stage-4 and stage-5) that are actively migrating downstream. Postponement of reproductive migration to increase the amount of stored fat may well be a strategy to optimise reproductive output. The monthly variation of metabolic and sexual maturation parameters in a downstream brackish estuary has been intensively studied (Van Ginneken et al. 2007b, c). However, the temporal variation of migration and maturation status at upstream regions over the months of the freshwater spawning run remains unclear.

The aim of this study was, therefore, to investigate the temporal changes in migratory status among silver eels in upstream regions over 3 months of the migration season (August, September and October). Furthermore, we have determined the maturation status in relation to the migratory status as indexed by Durif et al. (2005) to test the main hypothesis that freshwater migration stimulates previtellogenic oocyte development but not the subsequent vitellogenesis like we have observed after swimming eels in the laboratory. Maturation status was determined by analysing biometrical parameters, plasma $17 \beta$-estradiol (E2) and calcium (Ca) levels, oocyte histology and gonadal fat levels. In addition, we have determined age and checked aspects of their health status by measuring haematocrit (Hct), haemoglobin concentration $(\mathrm{Hb})$ and swim-bladder parasite Anguillicola crassus load as these parasites may significantly impair the migration capacity (Palstra et al. 2007b).

\section{Materials and methods}

Migrating silver eels and life transport

Experiments complied with the current laws of the Netherlands and were approved by the animal welfare committee (DEC). To reduce the mortality at hydropower stations in the Moselle (Germany), downstream-migrating eels are caught annually with fyke nets upstream from the hydropower stations $\left(3,000-5,000 \mathrm{~kg} \mathrm{year}^{-1}\right)$ and are then translocated 
downstream of these obstructions (Klein Breteler et al. 2007). Samples of these eels have been used for mark-recapture and telemetry studies (Klein Breteler et al. 2007; Breukelaar et al. 2009), and the health status of recaptured eels in The Netherlands has been determined (Haenen et al. 2010). Eels were caught with fyke nets upstream from the hydropower stations in the River Moselle (Germany) specifically aiming for those eels migrating downstream. The total numbers of eels caught were evenly spread during this year from August to October 2005 (Klein Breteler et al. 2007) without a clear migration peak. A total of 3,266 larger female eels were marked and released (Klein Breteler et al. 2007). Of these catches, subsamples of female eels were taken at August 24 $(n=10)$, September $22(n=9)$ and October 192005 $(n=10)$ for this study. From the release location near Cologne, the eels would still have to migrate $300-350 \mathrm{~km}$ in freshwater to reach the North Sea. For this study, the eels were live transported, first to the facilities of the former Organisation for Improvement of Inland Fisheries OVB (Nieuwegein, Then Netherlands) and followed within one day to the laboratory (Leiden, The Netherlands) in a $1 \mathrm{~kg}$ eel per 11 water ratio with 9 or 10 eels (respectively September or August and October) per 601 plastic bag filled up with oxygen.

\section{Biometry}

After arrival, eels were immediately anaesthetised with $1.5 \mathrm{ml}$ diluted clove oil per 1 water (oil of cloves: ethanol $=1: 10$ ) and then measured, photographed and dissected for sampling.

All eels were measured for body length (BL), body weight (BW) and biometric parameters on the left lateral side of the body eye diameter horizontal $(\mathrm{EDh})$, eye diameter vertical (EDv), pectoral fin length (PFL) and pectoral fin width (PFW). From these data, the following indices were calculated:

1. Condition factor $(\mathrm{K})=100 \times \mathrm{BW} \mathrm{BL}^{-3}$, with BW: body weight $(\mathrm{g}), \mathrm{BL}$ : body length $(\mathrm{cm})$;

2. Ocular index $(\mathrm{OI})=100 \times(((\mathrm{EDh}+\mathrm{EDv}) \times$ $\left.0.25)^{2} \pi \times(10 \times \mathrm{BL})^{-1}\right)$, with EDh: eye diameter horizontal $(\mathrm{mm}), \mathrm{EDv}$ : eye diameter vertical (mm) (Pankhurst 1982);

3. Pectoral fin length index $($ PFLI $)=100 \times$ PFL $\mathrm{BL}^{-1}$, with PFL: pectoral fin length $(\mathrm{cm})$;
4. Pectoral fin width index $(\mathrm{PFWI})=100 \times \mathrm{PFW}$ $\mathrm{BL}^{-1}$, with PFW: maximum pectoral fin width (cm); and

5. The silver index (SI) was calculated according to Durif et al. (2005).

Blood measurements

Blood samples were taken from the caudal vein with heparin flushed $\left(10,000 \mathrm{IU} \mathrm{ml}^{-1}\right) 1 \mathrm{ml}$ syringes, which were immediately placed on ice. Haematocrit (Hct) values were measured in $9 \mu \mathrm{l}$ whole blood samples as triplicates using a micro-centrifuge (Bayer, F.R.G.). Haemoglobin concentration (Hb) in $10 \mu \mathrm{l}$ was determined as duplicates by a spectrophotometer (LS50B, Perkin Elmer) measuring the absorbance at a fixed $\lambda$ of $550 \mathrm{~nm}$ using the MPR $3 \mathrm{kit}(1 \mathrm{ml}$, Roche Diagnostics $\mathrm{GmbH}$ ). Blood was centrifuged for $5 \mathrm{~min}$ at $14,000 \mathrm{rpm}$, and plasma was stored at $-80^{\circ} \mathrm{C}$.

As vitellogenic indicators in the blood plasma as shown in earlier studies (Palstra et al. 2010b, c), 17 $\beta$ estradiol (E2) and calcium (Ca), were chosen. E2 was measured by ELISA (human kit 55030, Human Gesellschaft fur Biochemica und Diagnostica mbH, Wiesbaden, Germany). Levels of plasma calcium were measured by a colorimetric test (human kit 10011, Human Gesellschaft fur Biochemica und Diagnostica mbH, Wiesbaden, Germany) and indicated circulating vitellogenin (Vtg). Ca was chosen as indirect measure of plasma $\mathrm{Vtg}$ in eels as previously reported by Versonnen et al. (2004) based on the significant positive correlation between $\mathrm{Ca}$ and $\mathrm{Vtg}$.

Tissue dissection

After sampling blood, eels were decapitated and liver, digestive tract and gonads were carefully dissected and weighted. From the dissected tissues, the following indices were calculated:

1. Gonadosomatic index $(\mathrm{GSI})=\left(\mathrm{GW} \times \mathrm{BW}^{-1}\right)$ $\times 100 \%$, with GW: gonad weight $(\mathrm{g})$, BW: body weight $(\mathrm{g})$;

2. Digestive tract somatic index $(\mathrm{DTSI})=(\mathrm{DTW}$ $\left.\times \mathrm{BW}^{-1}\right) \times 100 \%$, with DTW: weight digestive tract $(\mathrm{g})$; and

3. Hepatosomatic index $(\mathrm{HSI})=\left(\mathrm{LW} \times \mathrm{BW}^{-1}\right)$ $\times 100 \%$, with LW: liver weight $(\mathrm{g})$. 
Gonad tissue samples from a standardised rostral location were stored in Bouin solution at room temperature for histological analysis and at $-20^{\circ} \mathrm{C}$ for fat extraction. The swim bladder was carefully dissected and opened to count the number of swimbladder parasites present by naked eye. Migratory activity of the larvae of the swim-bladder parasite in the swim-bladder wall and the direct invasion of the preadults and adults in blood vessels results in a substantial thickening of the swim-bladder wall (Molnár et al. 1993; Beregi et al. 1998) and loss of transparency (Palstra et al. 2007b; Lefebvre et al. 2011). The transparency of the swim bladder was, therefore, staged (on a scale 1-4) and used as a measure of preinfection.

Oocyte histology, fat droplets and fat measurements

To remove the Bouin fixative, the gonads were washed in $0.1 \mathrm{M}$ phosphate buffer and $70 \%$ ethanol until the solution became transparent. Histological analysis was performed like described by Palstra et al. (2007a). In short, samples were embedded in air-free Technovit 7100 (Kulzer Histo-Technik) in Peel-A-way moulds (Polysciences Inc.) covered with a layer of air-free paraffin oil. Sections of $10 \mu \mathrm{m}$ thick were cut using a sledge microtome (Jung Polycut E), and sections were put on a slide and stained with Mayers Haematoxylin-Eosin. The oocytes were studied visually under the microscope (Nikon Eclipse E400), and overview pictures were taken (Nikon Coolpix 4500). For each section, ten oocytes were randomly selected that had been cut through the nucleus. The diameter of the oocytes (OD) in $\mu \mathrm{m}$ was determined using UTHSCSA Image Tool 2.0, and the number of fat droplets $(\mathrm{Fd})$ occurring in stage 3 oocytes (fat droplet stage/cortical alveolus stage; Palstra et al. 2007a) was counted. Gravimetric fat extraction of gonad tissue was performed as previously described by Murk et al. (1998) and calculated as percentage (Fat gon.).

Age estimation by otolithometry

Age estimation was carried out like described before by Palstra et al. (2007a, b) according to the method described by Daverat et al. (2005). The otoliths were embedded in synthetic resin (Synolith, Euroresins
Benelux BV, the Netherlands) and then polished to the nucleus using 2 different grits of sandpaper (1200 and 2400). Fine polishing was done by hand with $\mathrm{Al}_{2} \mathrm{O}_{3}$ (1 $\mu \mathrm{m}$ grain) on a polishing cloth. Etching was done using 5\% EDTA. A drop of this solution was applied on the mould for $3 \mathrm{~min}$. The otoliths were then rinsed with distilled water and stored in dry conditions. Year rings were visualised by staining with a drop of $5 \%$ toluidine blue and were then counted under a microscope. The age of each eel was determined by the number of increments starting from the nucleus, which was considered as year one of the eel's life.

\section{Statistical analysis}

Normal distribution was checked by Kolmogorov Smirnoff tests. Size differences between groups representing migratory stages were checked with a one-tailed ANOVA with Tukey correction. Significant size differences existed in BL between stage- 4 and stage- 5 and in BW between stage- 3 and stage- 4 and stage- 4 and stage-5. Because of this size difference, ANCOVA (two tailed) with BW as cofactor was performed for parameters $\mathrm{Hct}, \mathrm{Hb}$, number of parasites, E2, Ca, OD, Fd, relative (Fat gon.) and absolute gonadal fat levels (calculated by multiplying relative gonadal fat level with gonadal weight). However, only for $\mathrm{Ca}$, a significant size effect was present, and so for all other parameters, ANOVA with Tukey correction was applied. Indices OI, PFLI, PFWI, DTSI, HSI and GSI were compared using Kruskal-Wallis and Mann-Whitney $U$ tests (two tailed). All statistical analyses were performed with SPSS 16.0. Differences with $P \leq 0.05$ were considered significant. Values are expressed as average \pm standard error (SE). Principal component analysis (PCA) was performed using CANOCO (ter Braak and Šmilauer 2002) on log-transformed data with BW as covariant.

\section{Results}

Migratory stages

According to the staging procedure of Durif et al. (2005), six eels were in stage- 3 , nine eels in stage- 4 and fourteen eels in stage-5 (Fig. 1). Between the subsequent stages, increasing eye sizes were observed, an 

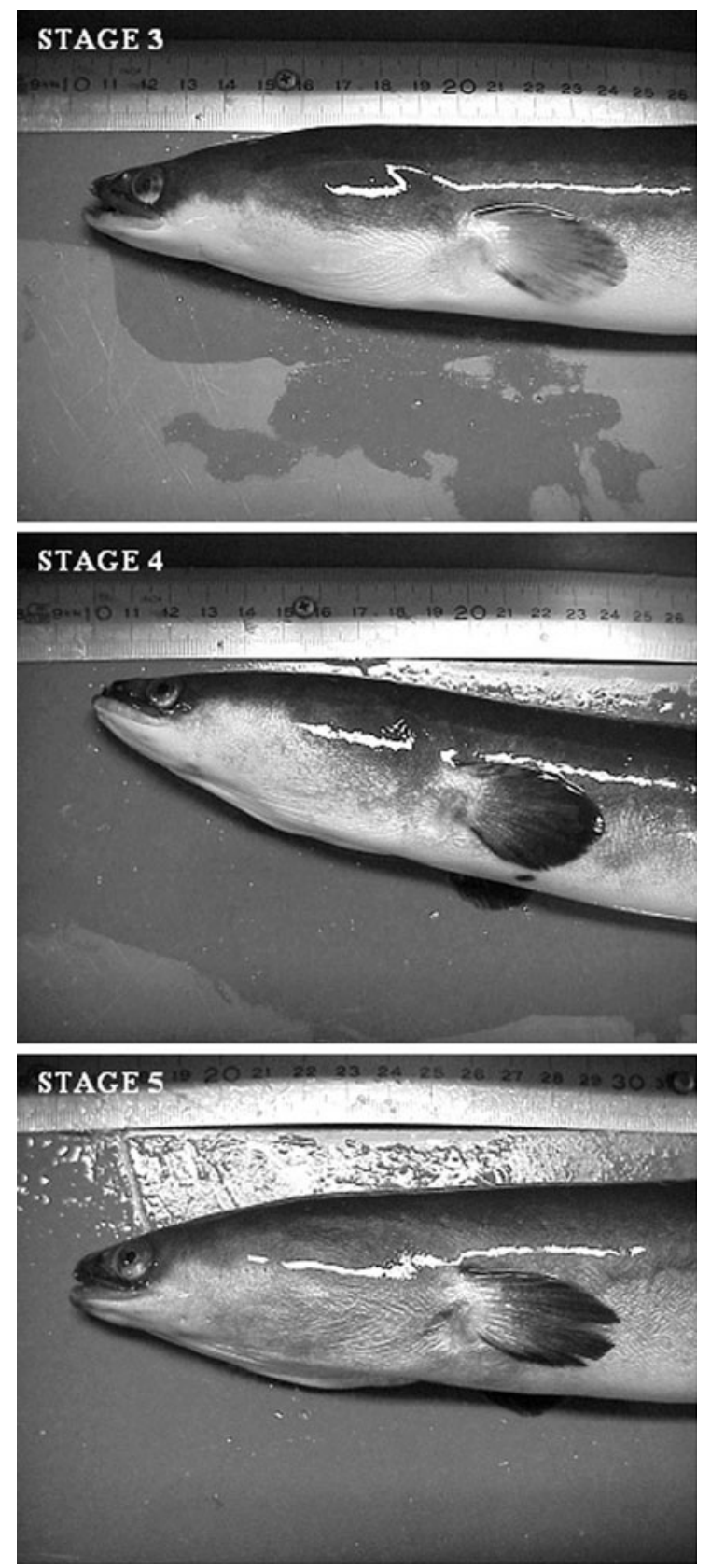

Fig. 1 Visual characterisation of silver eels at stage-3, stage-4 and stage-5 (after Durif et al. 2005). At each subsequent stage, there was an increase in eye size and darkening of the skin and pectoral fins

initial darkening of the skin and pectoral fin, and whitening of the belly from stage- 3 to stage- 4 . Thereafter, the dorsal skin becomes more bronze, the belly bronze-greyish and the centre of the pectoral fin silver from stage-4 to stage-5 (see Okamura et al. 2007
Table 1 Measured parameters $(\mathrm{AV} \pm \mathrm{SE})$ of silver eels of the three migratory stages

\begin{tabular}{|c|c|c|c|}
\hline & \multicolumn{3}{|l|}{ Migratory stage } \\
\hline & 3 & 4 & 5 \\
\hline$n$ & 6 & 9 & 14 \\
\hline Age (years) & $14 \pm 2$ & $14 \pm 1$ & $14 \pm 1$ \\
\hline $\mathrm{BL}(\mathrm{cm})$ & $79 \pm 2$ & $83 \pm 1$ & $74 \pm 1$ \\
\hline $\mathrm{BW}(\mathrm{g})$ & $900 \pm 69$ & $1,076 \pm 46$ & $763 \pm 25$ \\
\hline $\mathrm{CF}$ & $0.183 \pm 0.008$ & $0.189 \pm 0.004$ & $0.186 \pm 0.007$ \\
\hline OI & $7.71 \pm 0.32^{4,5}$ & $10.0 \pm 0.4^{3}$ & $11.0 \pm 0.4^{3}$ \\
\hline PFLI & $4.58 \pm 0.14$ & $4.54 \pm 0.15$ & $4.90 \pm 0.11$ \\
\hline PFWI & $2.91 \pm 0.21$ & $3.11 \pm 0.25$ & $2.99 \pm 0.18$ \\
\hline Hct $(\%)$ & $40.5 \pm 3.7$ & $38.7 \pm 2.2$ & $45.7 \pm 1.6$ \\
\hline $\mathrm{Hb}(\mathrm{mM})$ & $6.88 \pm 0.85$ & $7.85 \pm 0.28$ & $8.11 \pm 0.44$ \\
\hline DTSI & $2.21 \pm 0.35^{4}$ & $1.44 \pm 0.11^{3}$ & $1.63 \pm 0.18$ \\
\hline HSI & $1.25 \pm 0.09^{4}$ & $1.02 \pm 0.05^{3,5}$ & $1.17 \pm 0.04^{4}$ \\
\hline GSI & $1.13 \pm 0.10^{5}$ & $1.30 \pm 0.08$ & $1.49 \pm 0.07^{3}$ \\
\hline Parasites $(n)$ & $12 \pm 7$ & $6 \pm 4$ & $4 \pm 1$ \\
\hline $\mathrm{E} 2(\mathrm{pg} / \mathrm{ml})$ & $32.9 \pm 4.3$ & $48.7 \pm 8.3$ & $56.0 \pm 9.0$ \\
\hline $\mathrm{Ca}(\mathrm{mM})$ & $3.06 \pm 0.39$ & $2.72 \pm 0.04$ & $2.71 \pm 0.05$ \\
\hline OD & $153 \pm 6^{5}$ & $144 \pm 8^{5}$ & $177 \pm 4^{3,4}$ \\
\hline $\mathrm{Fd}$ & $25 \pm 5^{5}$ & $34 \pm 9^{5}$ & $61 \pm 4^{3,4}$ \\
\hline Fat gon. (\%) & $36 \pm 4^{5}$ & $34 \pm 3^{5}$ & $26 \pm 1^{3,4}$ \\
\hline
\end{tabular}

Significant $(P \leq 0.05)$ differences are given in bold, the superindex numbers state against which migratory stage the difference exists. Parameters shown are age; body length (BL); body weight (BW); condition factor (CF); ocular index (OI); pectoral fin length index (PFLI); pectoral fin width index (PFWI); haematocrit (Hct); haemoglobin ( $\mathrm{Hb})$; digestive tract index (DTSI); hepatosomatic index (HSI); gonadosomatic index (GSI); number of parasites; plasma 17 $\beta$ estradiol (E2); plasma calcium $(\mathrm{Ca})$; oocyte diameter (OD); number of fat droplets (Fd); and relative fat levels in the gonads (Fat gon.). Subsequent migratory stages show an increase in parameters OI, GSI, OD and Fd and a decrease in DTSI. Hct and HSI are lower at stage- 4 than at the other two stages. The percentual gonadal fat is lower at stage- 5 but the absolute fat level remains similar in relation to size

for a more detailed description in Japanese eel Anguilla japonica).

Slight differences in size were observed with stage-5 migrants that were significantly smaller than stage-3 premigrants and stage-4 migrants (Table 1). Despite these differences, eels of different stages were on average of the same age of 14 years.

In August, still 30\% of the silver eels were stage-3 premigrants and $70 \%$ was migrant. Among the migrants, $60 \%$ represented stage- 4 and $10 \%$ represented 


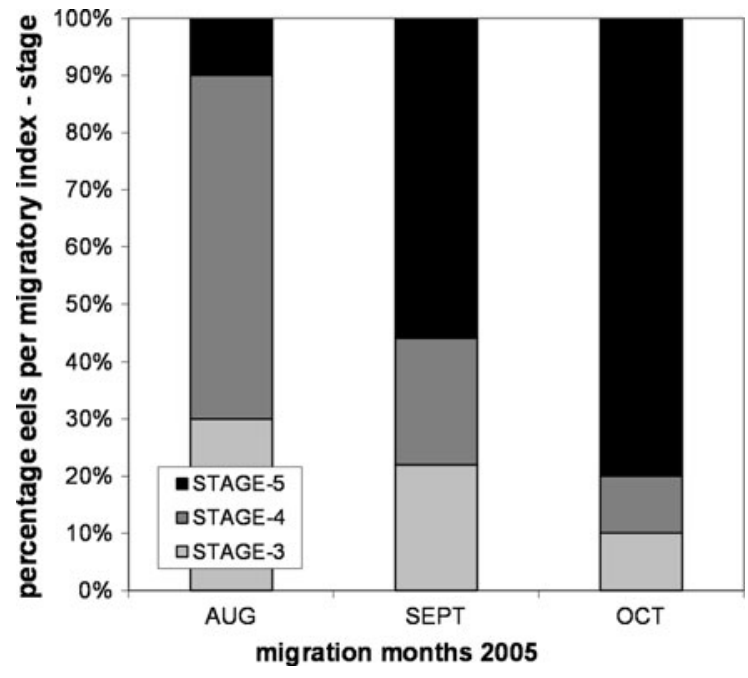

Fig. 2 Percentage of eels per silver index stage over 3 months $(n=29)$ of downstream migration at an upstream region of the River Rhine system (River Moselle) in Germany near Cologne. The percentage of stage-5 active migrants increases strongly over the months at the costs of both percentage of stage- 3 premigrants and stage- 4 migrants

stage-5 (Fig. 2). Percentages of stage-3 premigrants and stage-4 migrants decreased over the next 2 months of migration each down to $10 \%$, and the percentage of stage- 5 migrants increased to $80 \%$ in October.

Maturation and health status of migratory stages

Maturation parameters OI, GSI and OD increased significantly with each stage, with stage- 5 eels showing the highest values (Table 1). Plasma E2 did not show significant differences because of the high individual variation but a trend of increasing values seems apparent. Plasma $\mathrm{Ca}$ was neither different but significantly dependent on weight. Very clear was the increase in the number of fat droplets in oocytes of eels from stage-4 to stage-5 (Table 1; Fig. 3), indicating significant fat deposition. The fat percentage in the ovary decreased from $36 \pm 4 \%$ in stage- 3 premigrants and $34 \pm 3 \%$ in stage- 4 migrants to $26 \pm 1 \%$ in stage-5 migrants (Table 1). However, the GSI increased from stage-3 premigrants to stage-5 migrants (Table 1), resulting in a total amount of fat remaining similar between the stages: Stage- 3 eels had $3.6 \pm 0.6 \mathrm{~g}$ gonadal fat, stage- 4 eels had $5.0 \pm 1.0 \mathrm{~g}$ and stage- 5 eels $3.0 \pm 0.3 \mathrm{~g}$. Differences between groups were significant but strictly due to their weight differences.
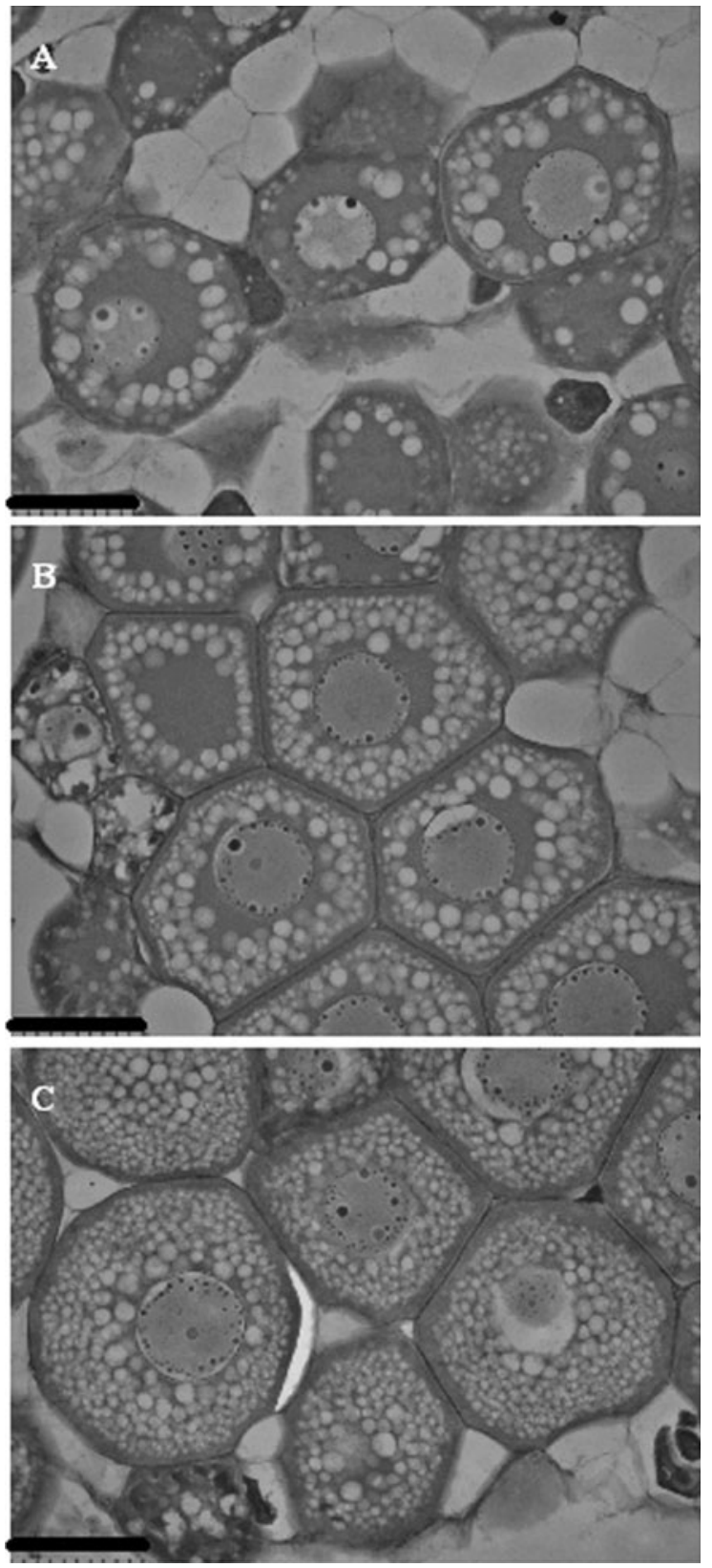

Fig. 3 Oocyte histology. Fat droplet distribution in oocytes of migrating silver eels. a Stage-3 premigrant in August, b Stage4 migrant in September and c Stage-5 migrant in October. The number of fat droplets in the oocytes increased and visual observation (not quantified) showed decreased extracellular lipid stores in the ovaries with each subsequent stage (HEStaining, bar represents $100 \mu \mathrm{m}$ )

HSI and DTSI were lower in stage-4 migrants than in stage-3 premigrants (Table 1). The HSI was $1.02 \pm 0.05$ in stage- 4 migrants versus $1.25 \pm 0.05$ in stage- 3 premigrants. The DTSI was $1.44 \pm 0.11$ in 
stage- 4 migrants versus $2.21 \pm 0.35$ in stage- 3 premigrants. In stage- 5 migrants, the HSI was significantly higher again than in stage- 4 migrants.

Hct values were on average $\sim 40 \%$ and similar for all stages. $\mathrm{Hb}$ values showed no significant changes but appeared to increase with each stage. Also no significant changes occurred in the number of parasites between eels of different stages although they seem to decrease. $69 \%$ of the silver eels had swim bladders containing swim-bladder parasites. Some individuals were infected at extremely high loads of 21, 39 and 46 nematodes per individual swim bladder (Fig. 4). Only $17 \%$ of the eels had healthy swim bladders that were not affected by (pre) infection as indicated by its complete transparency. At least $83 \%$ of the silver eels in this spawning run may have suffered from negative effects of swim-bladder parasites on their swimming performance.

Multivariate trends among parameters between the migratory stages

PCA was performed on the measured parameters with CANOCO (Fig. 5). Each arrow represents a parameter pointing in the direction of steepest increase, with angles between arrows indicating the significance of the correlation and the distance between the symbols in the diagram approximating the dissimilarity of the individuals and their group averages as measured by their Euclidean distance with BW as covariant. It thus illustrates the strong correlation (same direction of the arrows) among the 'maturation' parameters (OI, GSI, OD, Fd, E2) and age, contrary to parameters like DTSI and PFWI. The length of the arrows illustrates the effect that each parameter has on placing each individual and thus its importance in explaining the dissimilarity among individuals. The course of the migratory stages from stage- 3 to stage- 4 to stage- 5 is determined mainly by the maturation parameters. Some parameters like Hct, $\mathrm{Hb}$, HSI, number of parasites, PFLI and $\mathrm{Ca}$ do not show clear correlation with this development.

\section{Discussion}

This study shows a strong temporal progression in migratory stage among silver eels caught far upstream from the ocean during the months of the autumn spawning run. The applied catch method is
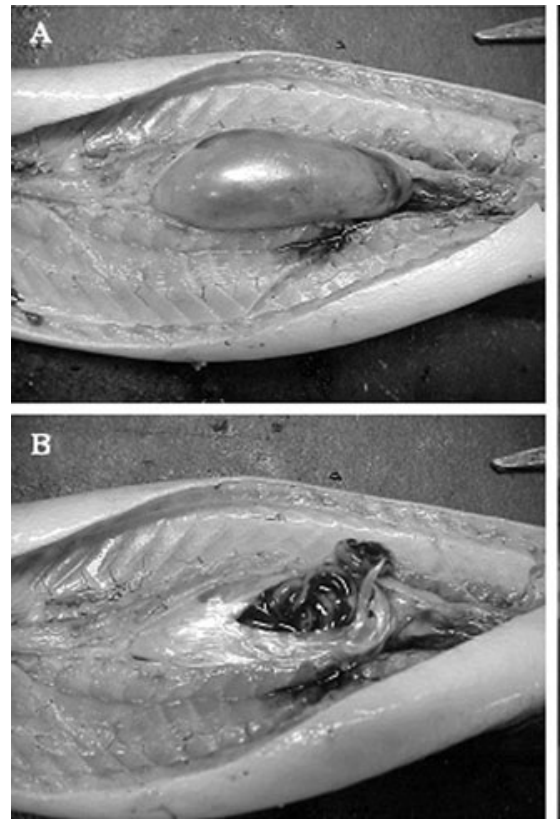

Fig. 4 Infection of migrating silver eels with the swimbladder parasite $A$. crassus. Most swim bladders were infected (69\%), some with extremely high loads of 21,39 and 46

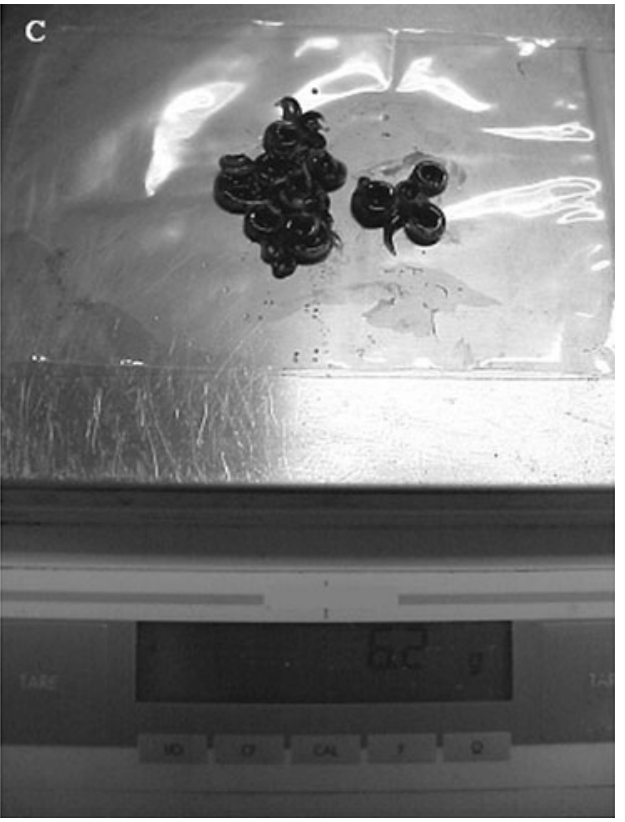

nematodes per individual swim bladder. From a-c, the swim bladder of this eel contained 39 nematodes with a total weight of $6.2 \mathrm{~g}$ 


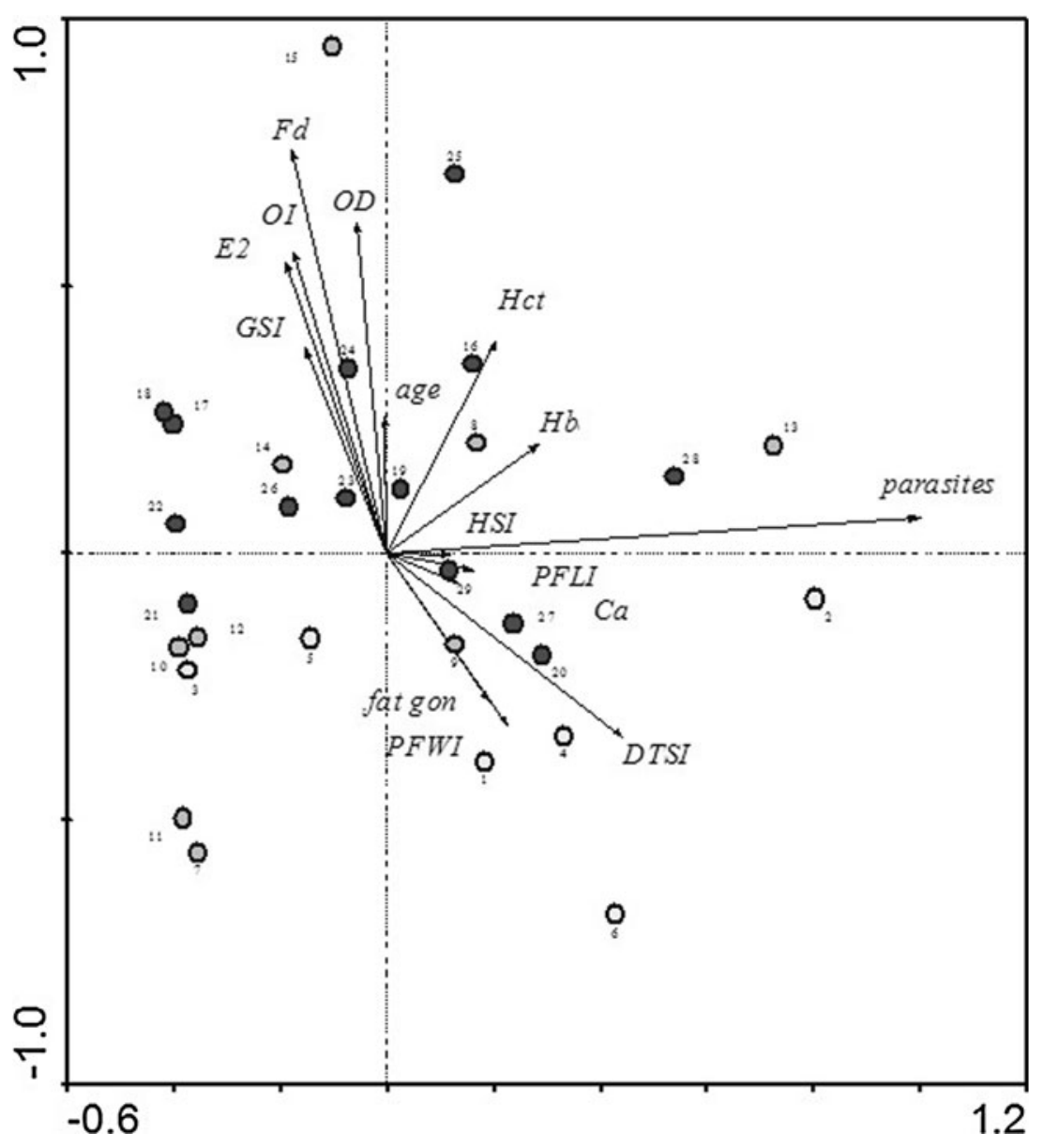

Fig. 5 CANOCO-PCA plot of all individuals of the three groups representing the migration months on basis of all measured parameters (log-transformed data) with body weight as covariate. Light coloured dots represent individuals of premigrant stage-3 (numbers 1-6), intermediate coloured dots of migrant stage-4 (numbers 7-15) and dark coloured spots of migrant stage-5 (numbers 16-29). A clear progression in maturation is illustrated from stage- 3 to stage- 4 to stage- 5 in

specifically aiming for catching migrant eels. If all caught eels would be reproductive migrants, then the index as developed by Durif et al. (2005) that makes a distinction between stage-3 premigrants and stage- 4 and stage-5 migrants is merely describing the temporal progression in silvering and does not have any relation with migration. However, these authors included the temporal variation in their extensive study. It therefore seems more logical that not all caught eels are reproductive migrants and that especially in August eels that represent premigrant stage-3 are caught during their feeding migrations. positive relation with parameters gonadosomatic index (GSI); plasma $17 \beta$ estradiol (E2); ocular index $(O I)$; number of fat droplets $(F d)$; oocyte diameter $(O D)$ and age; and negatively with digestive tract index (DTSI); pectoral fin width index $(P F W I)$ and relative fat levels in the gonads (fat gon). Other parameters include haematocrit $(H c t)$; haemoglobin concentration $(H b)$; hepatosomatic index $(H S I)$; number of parasites; pectoral fin length index (PFLI); and plasma calcium $(\mathrm{Ca})$

Additional argumentation would be that $47 \%$ of the eels that were used for the mark-recapture and telemetry studies in this project did not show downstream migration after release in the Rhine (Klein Breteler et al. 2007). Other similar studies have also reported on significant numbers of eels that do not migrate downstream (Durif et al. 2005; Winter et al. 2006; Breukelaar et al. 2009). Moreover, these eels may especially be those caught early in the migration season (Fig. 3 in Klein Breteler et al. 2007) that would agree with our conclusion that catches are a mix of reproductive migrants and feeding migrants 
of which the ratio increases over the months of downstream migration. Durif's index would, therefore, indicate the migratory status of the silver eels well and should be applied in mark-recapture and telemetry studies and others that aim for reproductive migrants. The efforts to reduce the mortality at hydropower stations of downstream-migrating eels in the Moselle (Germany) by translocating them is only applicable to the reproductive migrants and can be limited to a stricter period of reproductive migration. Other measures should be applied to prevent mortality among feeding migrants.

Furthermore, this study has shown that downstream migration is strictly linked to the maturation status as indicated by enlargement of the eyes, oocyte growth and fat deposition in the oocytes. Our laboratory studies where we have used exercise experimentally to study its effects on the onset of sexual maturation (Palstra et al. 2007a; reviewed by Palstra et al. 2009; Palstra and van den Thillart 2010) have revealed that swimming in freshwater as performed by migrant eels was found to stimulate the early sexual maturation. The eels used in these studies were starved and swum under continuous red light at a constant water temperature of $18^{\circ} \mathrm{C}$. Those results show that although other environmental factors may play a role in the field, exercise alone can act as a main trigger for early maturation defined by the fat vesicle stage (Adachi et al. 2003; Wallace and Selman 1981; Tyler and Sumpter 1996). Silver eels have been reported to have a higher activity than yellow eels (van Ginneken et al. 2005) as well as higher cortisol levels (van Ginneken et al. 2007b). Cortisol may be responsible for lipid mobilisation to fuel swimming exercise but may also play a role in lifting the dopaminergic inhibition of sexual maturation in female eels (Dufour et al. 2003; Palstra et al. 2008, 2010c), perhaps by binding to glucocorticoid receptor-expressing neurons (Teitsma et al. 1999). The shipment from Germany to The Netherlands of the eels in this study caused too much handling, which prevented to measure cortisol as trustable parameter.

A progression of migratory stages, as well as swimming exercise as shown in our earlier studies, is clearly linked to increased fat deposition in the oocytes (Fig. 3). However, the absolute fat level in the gonads remained similar over all the migratory stages in relation to size. ANCOVA showed that heavier eels did have significantly higher absolute gonadal fat levels suggesting an increased capacity of these eels to transfer fat from the muscle to the gonads (also Palstra et al. 2006). As egg quality depends heavily on incorporation of reserves, this increased capacity suggests a higher reproduction potency. The fact that the various stages had similar gonadal fat levels shows that the fat should already be present in the extracellular stores of gonads, which is also illustrated by Fig. 3. So maybe not the fat translocation to the gonad is stimulated during these stages of migration but specifically the fat uptake by the oocytes.

The positive correlation between eye size and oocyte development was already experimentally shown by Pankhurst (1982) and is probably caused by increased levels of plasma 11-ketotestosterone in female eels (Lokman et al. 2003). Besides stimulation of the enlargement of the eyes (Rohr et al. 2001), 11-ketotestosteron is also involved in the regulation of lipid uptake by the eel oocytes. In vitro experiments using previtellogenic ovarian fragments from short-finned eel Anguilla australis have shown that 11-ketotestosteron stimulates oocyte growth and is involved in fat deposition in the oocytes (Lokman et al. 2007) of specifically very low density lipoprotein (VLDL; Endo et al. 2008). Studies on lipoprotein receptors in rainbow trout Oncorhynchus mykiss (Prat et al. 1998) and coho salmon Oncorhynchus kisutch (Luckenbach et al. 2008) have suggested that the somatic lipoprotein receptor is involved in the uptake of lipoproteins other than vitellogenin and is already present during the previtellogenic stage. Lipoprotein lipase (LPL) may play an important role in facilitation of lipid transport across biological membranes and in lipid uptake associated with secondary oocyte growth (Luckenbach et al. 2008). In the short-finned eel, in vitro LPL mRNA levels increased dramatically upon 11-ketotestosteron treatment suggesting that ovarian LPL is directly involved in the uptake of lipids under regulatory control by 11-ketotestosteron (Divers et al. 2010). Future swimming trials of female European eels should include measurements on plasma 11-KT and determination of expression of lipoprotein receptors, LPL and other important genes involved in the regulation of lipid uptake to study the stimulating effects of exercise.

A rise of plasma E2 levels as a result of gonadal development was not significant (yet) but was strictly 
correlated to the gonadal development (Fig. 5). Hepatic vitellogenesis is not activated as indicated by the low plasma $\mathrm{Ca}$ levels. Liver sensitivity may occur only upon seawater entry after downstream migration as $\mathrm{Ca}$ and vitellogenin levels in freshwater eels are not detectable (Versonnen et al. 2004; Palstra and van den Thillart 2010), but in the brackish estuaries, some silver eels show increased plasma vitellogenin levels (Palstra and van den Thillart 2010). The absence of vitellogenesis in European eels in freshwater is in contrast to Anguilla species that need to migrate lesser distance to the spawning grounds like wild New Zealand freshwater eels Anguilla dieffenbachii and A. australis (Lokman et al. 1998). One of the silvering phenomena is known to be a regression of the digestive tract (reviewed by Lokman et al. 2003; Durif et al. 2009) which explains the lower DTSI with increasing migration stage that will prevent the eels from feeding. Also the lowering of the HSI as indicator of liver activity may be related to a cessation of feeding and not with hepatic production of vitellogenin.

\section{Conclusions}

We can conclude that the percentage of migrants in the population strongly increases from August to October. Clear differences in the state of sexual maturation existed among silver eels. Active migrants (stage-4 and stage-5 according to Durif et al. 2005) were in a much more progressed state of maturation as compared to the premigrants (stage-3). Migrants show extensive fat uptake by the oocytes, probably activated by swimming exercise. Previtellogenic oocyte development is indeed stimulated during migration as we hypothesised. Vitellogenesis has not yet been activated.

Acknowledgments Eels were caught in the yearly trap-andrelease actions by the Struktur und Genehmigungsbehörde Nord (Rheinland-Pfalz), intended to help the silver eels with passing the hydropower stations in the River Moselle. The Rheinfischereigenossenschaft of Nortrhine-Westfalia, the Landesanstalt für Ökologie, Bodenordnung und Forsten NRW (LÖBF), the Rheinischer Fischereiverband Nordrhein e.V., the Organisation for Improvement of Inland Fisheries (OVB) and Sportvisserij Nederland all contributed to the field work. The authors wish to acknowledge M. de Bakker and M. Nieveen for their technical assistance. AP was supported by a Marie Curie
Intra-European Fellowship from the European Commission (REPRO-SWIM) with Grant Agreement number 219971.

Open Access This article is distributed under the terms of the Creative Commons Attribution Noncommercial License which permits any noncommercial use, distribution, and reproduction in any medium, provided the original author(s) and source are credited.

\section{References}

Adachi S, Ijiri S, Kazeto Y, Yamauchi K (2003) Oogenesis in the Japanese Eel, Anguilla japonica. In: Aida K, Tsukamoto K, Yamauchi K (eds) Eel biology. Springer-Verlag, Tokyo, pp 502-518

Aroua S, Schmitz M, Baloche S, Vidal B, Rousseau K, Dufour S (2005) Endocrine evidence that silvering, a secondary metamorphosis in the eel, is a pubertal rather than a metamorphic event. Neuroendocrinology 82:221-232

Beregi A, Molnár K, Békési L, Cs Székely (1998) Radiodiagnostic method for studying swim-bladder inflammation caused by Anguillicola crassus (Nematoda: Dracunculoidea). Dis Aquat Org 34:155-160

Breukelaar AW, Ingendahl D, Vriese FT, de Laak G, Staas S, Klein Breteler JPG (2009) Route choices, migration speeds and daily migration activity of European silver eels Anguilla anguilla in the River Rhine, north-west Europe. J Fish Biol 74:2139-2157

Daverat F, Gazeau-Naudin C, Camoin P-Cemagref Bordeaux (2005). Eel otolith preparation for ageing. CD-ROM

Divers SL, McQuillan HJ, Matsubara H, Todo T, Lokman PM (2010) Effects of reproductive stage and 11-ketotestosterone on LPL mRNA levels in the ovary of the shortfinned eel. J Lipid Res 51:3250-3258

Dufour S, Burzawa-Gerard E, Le Belle N, Sbaihi M, Vidal B (2003) Reproductive endocrinology of the European eel, Anguilla anguilla. In: Aida K, Tsukamoto K, Yamauchi K (eds) Eel biology. Springer, Tokyo, pp 373-384

Durif C, Dufour S, Elie P (2005) The silvering process of Anguilla anguilla: a new classification from the yellow resident to the silver migrating stage. J Fish Biol 66:1025-1043

Durif CMF, van Ginneken V, Dufour S, Müller T, Elie P (2009) Seasonal evolution and individual differences in silvering eels from different locations. In: van den Thillart G, Dufour S, Rankin C (eds) Spawning migration of the European eel. Springer, Netherlands, pp 13-38

Endo T, Todo T, Lokman PM, Ijiri S, Adachi S, Yamauchi K (2008) In vitro induction of oil droplet accumulation into previtellogenic oocytes of Japanese eel, Anguilla japonica. Cybium 32:239-240

Haenen OLM, Lehmann J, Engelsma MY, Stürenberg FJ, Roozenburg I, Kerkhoff S, Klein Breteler J (2010) The health status of European silver eels, Anguilla anguilla, in the Dutch River Rhine watershed and lake Ijsselmeer. Aquaculture 309:15-24

Klein Breteler J, Vriese T, Borcherding J, Breukelaar A, Jörgensen L, Staas S, de Laak G, Ingendahl D (2007) 
Assessment of population size and migration routes of silver eel in the River Rhine based on a 2-year combined mark-recapture and telemetry study. ICES J Mar Sci 64:1450-1456

Lefebvre F, Fazio G, Palstra AP, Székely C, Crivelli AJ (2011) An evaluation of indices of gross pathology associated with the nematode Anguillicoloides crassus in eels. J Fish Dis 34:31-45

Lokman PM, Vermeulen GJ, Lambert JGD, Young G (1998) Gonad histology and plasma steroid profiles in wild New Zealand freshwater eels (Anguilla dieffenbachii and $A$. australis) before and at the onset of the natural spawning migration. I. Females. Fish Physiol Biochem 19:325-338

Lokman PM, Rohr DH, Davie PS, Young G (2003) The physiology of silvering in anguillid eels: androgens and control of metamorphosis from the yellow to silver stage. In: Aida K, Tsukamoto K, Yamauchi K (eds) Eel biology. Springer, Tokyo, pp 331-350

Lokman PM, George KAN, Divers SL, Algie M, Young G (2007) 11-Ketotestosterone and IGF-I increase the size of previtellogenic oocytes from the shortfinned eel, Anguilla australis, in vitro. Reproduction 133:955-967

Luckenbach JA, Iliev DB, Goetz FW, Swanson P (2008) Identification of differentially expressed ovarian genes during primary and early secondary oocyte growth in coho salmon, Oncorhynchus kisutch. Reprod Biol Endocrinol 6:2

Molnár K, Baska F, Csaba Gy, Glávits R, Cs Székely (1993) Pathological and histopathological studies of the swimbladder of eels Anguilla anguilla infected by Anguillicola crassus (Nematoda: Dracunculoidea). Dis Aquat Org 15:41-50

Murk AJ, Leonards PEG, van Hattum B, Luit R, van der Weiden MEJ, Smit M (1998) Application of biomarkers for exposure and effect of polyhalogenated aromatic hydrocarbons in naturally exposed European otters (Lutra lutra). Environ Toxicol Pharmacol 6:91-103

Okamura A, Yamada Y, Yokouchi K, Horie N, Mikawa N, Utoh T, Tanaka S, Tsukamoto K (2007) A silvering index for the Japanese eel Anguilla japonica. Environ Biol Fishes 80:77-89

Palstra AP, van den Thillart G (2010) Swimming physiology of eels: energetic costs and effects on sexual maturation and reproduction. Fish Physiol Biochem 36:297-322

Palstra AP, van Ginneken VJT, Murk AJ, van den Thillart GEEJM (2006) Are dioxin-like contaminants responsible for the eel (Anguilla anguilla) drama? Naturwissenschaften 93:145-148

Palstra A, Curiel D, Fekkes M, de Bakker M, Székely C, van Ginneken V, van den Thillart G (2007a) Swimming stimulates oocyte development in European eel (Anguilla anguilla $\mathrm{L}$.). Aquaculture 270:321-332

Palstra AP, Heppener DFM, van Ginneken VJT, Székely C, van den Thillart GEEJM (2007b) Swimming performance of silver eels is severely impaired by the swim-bladder parasite Anguillicola crassus. J Exp Mar Biol Ecol 352:244-256

Palstra AP, Schnabel D, Nieveen MC, Spaink HP, van den Thillart GEEJM (2008) Male silver eels mature by swimming. BMC Physiol 8:14

Palstra AP, van Ginneken V, van den Thillart G (2009) Effects of swimming on silvering and maturation. In: van den
Thillart G, Dufour S, Rankin C (eds) Spawning migration of the European eel. Springer, Netherlands, pp 309-332

Palstra AP, Crespo D, van den Thillart GEEJM, Planas JV (2010a) Saving energy to fuel exercise: swimming suppresses oocyte development and down-regulates ovarian transcriptomic response of rainbow trout Oncorhynchus mykiss. Am J Physiol Regul Integr Comp Physiol 299:R486-R499

Palstra A, Schnabel D, Nieveen M, Spaink H, van den Thillart G (2010b) Temporal expression of hepatic estrogen receptor 1, vitellogenin1 and vitellogenin 2 in European silver eels. Gen Comp Endocrinol 166:1-11

Palstra AP, Schnabel D, Nieveen M, Spaink HP, van den Thillart G (2010c) Swimming suppresses hepatic vitellogenesis in European silver eel as shown by quantitative RT-PCR of the estrogen receptor 1, vitellogenin1 and vitellogenin2 in the liver. Reprod Biol Endocrinol 8:27

Pankhurst NW (1982) Relation of visual changes to the onset of sexual maturation in the European eel Anguilla anguilla (L.). J Fish Biol 21:127-140

Prat F, Coward K, Sumpter JP, Tyler CR (1998) Molecular characterization and expression of two ovarian lipoprotein receptors in the rainbow trout, Oncorhynchus mykiss. Biol Reprod 58:1146-1153

Rohr DH, Lokman PM, Davie PS, Young G (2001) 11-Ketotestosterone induces silvering-related changes in immature female short-finned eels, Anguilla australis. Comp Biochem Physiol A 130:701-714

Svedäng H, Wickström H (1997) Low fat contents in female silver eels: indications of insufficient energetic stores for migration and gonadal development. J Fish Biol 50:475-486

Teitsma CA, Anglade I, Lethimonier C, Le Dréan G, Saliguat D, Ducouret B, Kah O (1999) Glucocorticoid receptor immunoreactivity in neurons and pituitary cells implicated in reproductive functions in rainbow trout: a double immunohistochemical study. Biol Reprod 60:642-650

Ter Braak CJF, Šmilauer P (2002) CANOCO reference manual and canodraw for windows user's guide: software for canonical community ordination (version 4.5). Microcomputer, Ithaca

Tesch FW (1972) Versuche zur telemetrischen Verfolgung der Laichwanderung von Aalen (Anguilla anguilla) in der Nordsee. Helgol Mar Res 23:165-183

Tyler CR, Sumpter JP (1996) Oocyte growth and development in teleosts. Rev Fish Biol Fish 6:287-318

Van den Thillart G, Palstra A, van Ginneken V (2009) Energy requirements of European eel for trans atlantic spawning migration. In: van den Thillart G, Dufour S, Rankin C (eds) Spawning migration of the European eel. Springer, Netherlands, pp 179-200

Van Ginneken V, Muusze B, Klein Breteler J, Jansma D, van den Thillart G (2005) Microelectronic detection of activity level and magnetic orientation of yellow European eel, Anguilla anguilla $L$., in a pond. Environ Biol Fishes 72:313-320

Van Ginneken V, Dufour S, Sbaihi M, Balm P, Noorlander K, de Bakker M, Doornbos J, Palstra A, Antonissen E, Mayer I, van den Thillart G (2007a) Does a 5, 500-km swim trial stimulate early sexual maturation in the European eel (Anguilla anguilla L.)? Comp Biochem Physiol A 147:1095-1103 
Van Ginneken V, Durif C, Dufour S, Sbaihi M, Boot R, Noorlander K, Doornbos J, Murk AJ, van den Thillart G (2007b) Endocrine profiles during silvering of the European eel (Anguilla anguilla L.) living in saltwater. Anim Biol 57:453-465

Van Ginneken V, Durif C, Balm SP, Boot R, Verstegen MWA, Antonissen E, van den Thillart G (2007c) Silvering of European eel (Anguilla anguilla L.): seasonal changes of morphological and metabolic parameters. Anim Biol 57:63-77
Versonnen BJ, Goemans G, Belpaire C, Janssen CR (2004) Vitellogenin content in European eel (Anguilla anguilla) in Flanders, Belgium. Environ Pollut 128:363-371

Wallace RA, Selman K (1981) Cellular and dynamic aspects of oocyte growth in teleosts. Am Zool 21:325-343

Winter HV, Jansen HM, Bruijs MC (2006) Assessing the impact of hydropower and fisheries on downstream migrating silver eel, Anguilla anguilla, by telemetry in the River Meuse. Ecol Freshw Fish 15:221-228 